\title{
MPR TO SUPPORT THE SALES OF ICT EDUCATION
}

\author{
Didier Neonisa \\ Jurusan Marketing Communication, Fakultas Komunikasi dan Multimedia, \\ Bina Nusantara University, Jln. K.H. Syahdan No. 9, Palmerah Jakarta Barat 11480
}

\begin{abstract}
In the era of globalization the development of economy in each country is determined on how they develop and utilize Information and Communication Technology (ICT) in their business activity. However, Marketing Public Relations (MPR) is also the most appropriate strategy for Education institute, because in nature education institute has to create long term relationship with their student. Therefore MPR should at least encompass three disciplines of studies and professions, in which are strategic management, marketing and public relations. For BINUS Center, awareness can be gain through referral activity. Advocacy or referral have dominant effect in building trust (believe), other than that publication also play a role in creating a trustworthy image towards BINUS Center. Marketing Public Relation is an effective marketing strategy for ICT education. Based on the quantitative research the majority of BINUS Center target market is in the age bracket 18-22 years old. In correlation with that fact the qualitative research has shown that MPR is effective in supporting the enrollment decision towards BINUS Center.
\end{abstract}

Keywords: ICT, MPR, education, BINUS Centre, quantitative

\begin{abstract}
ABSTRAK
Pada era globalisasi, perkembangan ekonomi di tiap negara ditentukan oleh bagaimana mereka mengembangkan dan menggunakan teknologi informasi dan komunikasi (ICT) dalam aktivitas bisnis. Selain itu, MPR (Marketing Public Relation) berperan sebagai strategi paling sesuai untuk institusi pendidikan, karena institusi pendidikan akan menciptakan hubungan jangka panjang dengan para pelajar. Karenanya, MPR setidaknya meliputi tiga disiplin ilmu dalam pembelajaran dan profesi, yaitu strategi manajemen, marketing, dan public relations. Untuk BINUS Center, kepedulian bisa ditingkatkan melalui advokasi, yang memiliki efek domino dalam peningkatan kepercayaan, daripada menggunakan publikasi yang juga berperan dalam menciptakan citra BINUS Centre. MPR adalah strategi marketing yang efektif untuk pendidikan ICT. Berdasarkan penelitian kuantitatif, mayoritas target market BINUS Center termasuk dalam usia 18-22 tahun. Karenanya, penelitian menunjukkan bahwa MPR efektif dalam mendukung peningkatan marketing dan citra BINUS Center.
\end{abstract}

Kata kunci: ICT, MPR, pendidikan, BINUS Center, kuantitatif 


\section{INTRODUCTION}

In the era of globalization the development of economy in each country is determined on how they develop and utilize Information and Communication Technology (ICT) in their business activity. Dodi Nandika (2007) believed that the modern economy will emphasize more on intellectual competence of human resources rather than the hard asset of natural resources; such is the foundation for knowledge based economy.

Dr. Robert B. Kozma (2005), a researcher on education and ICT development also stated that the pervasiveness of ICT has changed the way people live, work and play. New knowledge and the use of new technologies have resulted in the creation of new products, services, and jobs, which were unimaginable a few decades before.

Based on that notion the writer is led to believe that, the old agrarian and industrial societies in the past have shifted towards knowledge-based societies, where advanced ICT supports the exchange of information without time or location constraints. Therefore the ability to utilize knowledge to increase productivity is considered to be a vital skill in creating opportunities and boosting the competitiveness.
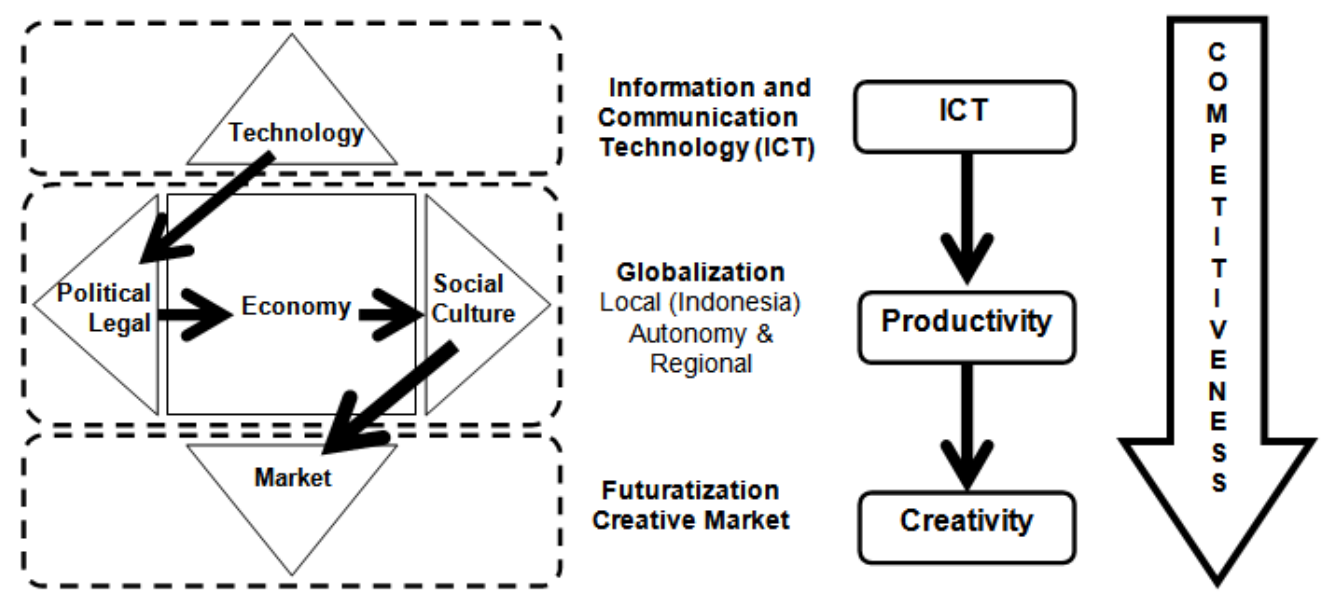

Figure 1 Diagram on ow ICT drives the market Source Kotler et al, 2003

A research done by Department of Information and Communication shows that, the development of ICT in Indonesia can be predictable through the increase use of ICT products. According to Suciptoardi (2008), in 2007, Indonesia has experienced a $48 \%$ growth, especially in cellular market that has managed to achieve a $51 \%$ growth and $78 \%$ growth in FWA (Fixed Wireless Access, widely known as CDMA), as a comparison with the previous year's result. Besides these results, it has also been reported that the ownership of personal computers (PCs) within the society has grown significantly to $38.5 \%$. The number of Internet users has also grown to 2 million users or $23 \%$ more in comparison to 2006.

Deriving from that fact, the writer believes that future societies are driven by ICT, which is why Indonesian government started to shift their development plan unto that area. 


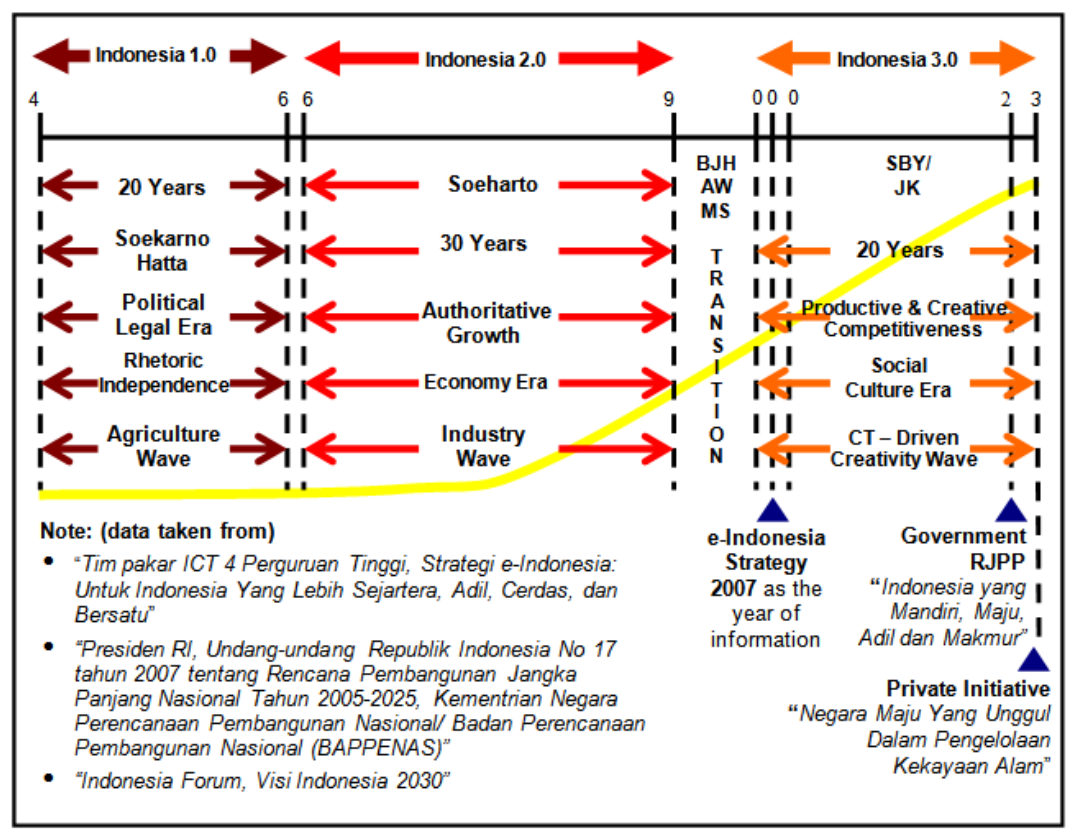

Figure 2 Development of ICT in Indonesia Source Kotler et al, 2003

From the diagrams above (Figure 2), it is prudent to believe that ICT literacy would be a crucial skill for Indonesian societies in the future. Therefore such condition will boost the growth of ICT education institute in Indonesia.

\section{The Rise of ICT Education}

The emerging trends of ICT development have put tremendous stress on Indonesia education system. Therefore, "in order to adapt to the emerging knowledge based society and enhance national competitiveness, the people must learn new skills, which is why education should build on a person's natural skill and encourage them to look towards the future" (Kim 2003). According to the research done by Tempo magazine in 2006-2007, ICT Literacy has been considered as common test for hiring an employee.

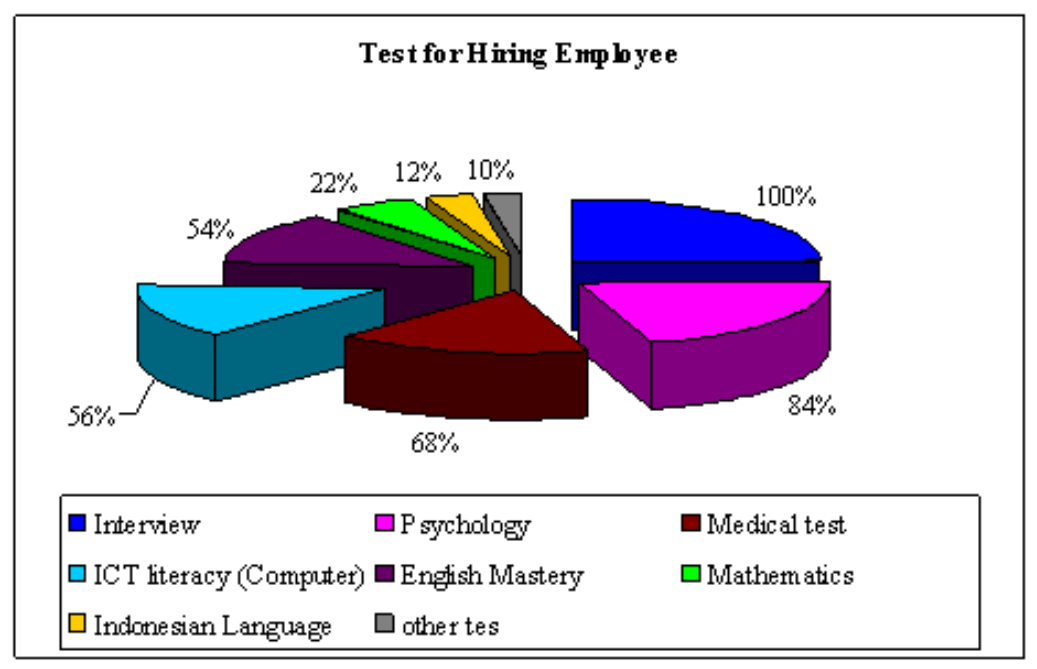

Figure 3 Chart on ICT test for employee

Source: Tempo, 2007 
From the chart above, the writer may perceive that companies (industries) in Indonesia have considered ICT literacy as on of the main reason for recruiting an employee. Unfortunately the numbers of ICT literacy among Indonesian workforce is still very low. Sofyan Djalil, the minister of Information and Communication Department, stated that, "at this time the discrepancy of demand and supply of ICT literate human resources in Indonesia is quite immense, with a staggering number of $300 \%$. However that number is expected to decrease to $165 \%$ by the year 2008" (Depkominfo 2006).

Another research done by International Development Center (IDC), shows that "the revenue of ICT field in Indonesia on 2007 is predicted to be 1.720 million dollars, with a presentation of $0,7 \%$ GDP. Other than that the number of company that specializing on ICT would reach a total number of 7.141 , this means that these companies will need at least 164.250 of ICT literate human resources" (Depkominfo, 2006). Therefore based on the 2 facts, it is prudent to conclude that, the key to successfully increase ICT literacy among the Indonesian society is through constant development of ICT education institute.

\section{The Role of Marketing Public Relations}

According to Chapter 31 of the 1945 Indonesia State Law, Indonesian citizens are entitled to have proper education. This means that Indonesian citizens have the right to be educated and the right is protected by the law. Therefore some people are led to believe that education should not be treated like an Industry. However WTO (World Trade Organization) has changed that old paradigm in 2005. According to WTO education should be considered as business opportunities in the future. From that point of view it is clearly that every education institute in the world would be facing a fierce competition. Through a research done by Department of Information and Communication, it shows that in Indonesia there are 200 education institutes that offer ICT based curriculum on the level of S1 to doctoral degree, while there are 300 more education institute that offers the same curriculum on the level of diploma degree. An underlying assumption of the paragraph above is that, unless an ICT education Institute successfully marketed its product or services, it could not survive, and that, therefore its relationship with its various public are inevitably intertwined with marketing.

For education institute, the marketing activity is designed to shape positive image in order to influence the target market. Therefore in this research the writer suggested the role of Marketing Public Relations in the process to support the sales of ICT education. According to Kotler \& Armstrong "Public Relations can have strong impact on public awareness at a much lower cost than advertising" (2004). Other than that the writer believes that Public Relations also offer company a way to distinguish them self and their products from the competitor. Although there have been numerous articles and books concerning Public Relations development in a marketing sense, little or nothing has been written concerning its development within ICT education institute. Therefore the writer believes that this research will help education institute in applying MPR to build credible communication strategy, which shapes a positive image, and create good relationship.

\section{Literature Review}

The study is influenced by two theories, which will help the writer in analyzing and interpreting the data recovered in this research, the theories are as follows:

\section{Marketing Public Relations}

Marketing Public Relations is about the long-term rather than the short-term. Such notion formulates MPR as the most appropriate strategy for Education institute, because in nature education institute has to create long term relationship with their student. Thomas L. Harris describes MPR as: 
Marketing Public Relations is the use of public relation strategies and techniques to achieve marketing objectives. The purpose of MPR is to gain awareness, stimulate sales, facilitate communication, and build relationship between consumers and companies and brands. The principal functions of MPR are the communication of credible information, the sponsorship, and the support of causes that benefit society. (Alifahmi, 2008).

Therefore MPR should at least encompass three disciplines of studies and professions, in which are strategic management, marketing and public relations. Those three disciplines and profession will forms the golden triangle of MPR, which described as in Figure 4.

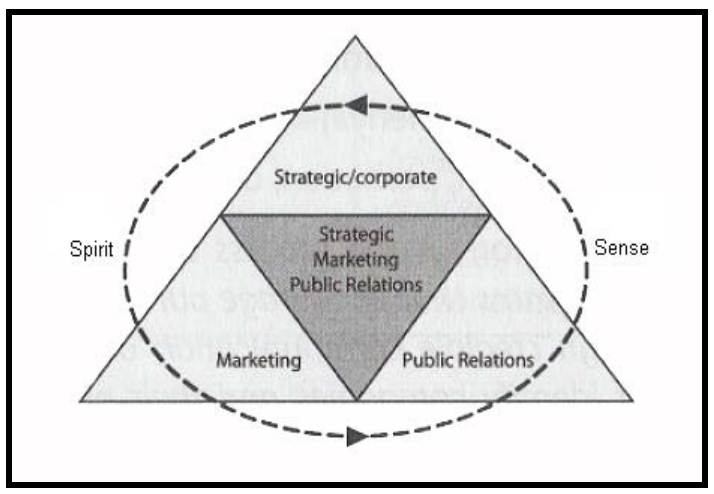

Figure 4 Golden Triangle of MPR

Source: Alifahmi, 2008

Kotler \& Mindak (1997) have also developed a model which describes the relationship between public relations and marketing. The model encompasses five alternative arrangements, in which as follows (Ranchhod, et al, 2008): separate but equal functions, separate but overlapping functions, marketing as the dominant function, public relation as the dominant function, and marketing and public relation as converging functions.

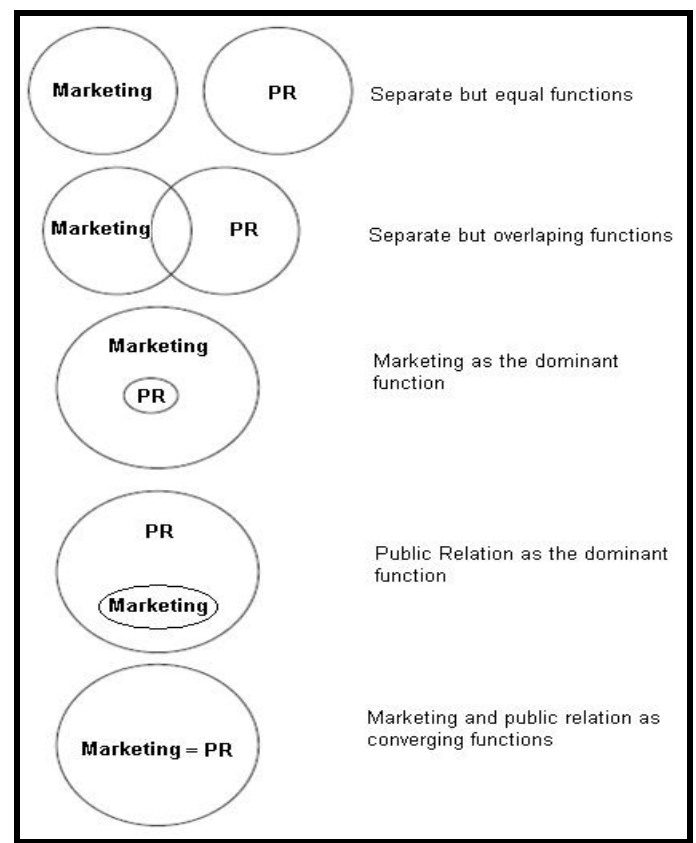

Figure 5 Five Alternatives Model of PR and Marketing Source: Ranchhod et al, 2008 
To ensure the Marketing Public Relations strategy running smoothly, it requires a proper tool to reach the public. According to Paul Copley there are several effective tools to reach the public in terms of MPR. However, according to Copley (2004), on the objective of this study the writer will only cite several tools that are considered effective for ICT education institute. In which are as follows: (1) seminars and conference, a sponsored activity connected with a specific subject, in order to influence a specific target groups; (2) brochure, contain either general purpose, corporate information or can be designed to communicate information on specific topics; (3) exhibition, shows for general public or trade or both and can be part of wider event; (4) Web news page and e-mail, the use of websites, web page, and e-mail decreases the importance of traditional gate keepers, and offers opportunities to profile employees, outline business philosophy, and provide information on investment, to name but a few activities. An effective Marketing Public Relations program blends all of the strategy and tools to reach the public.

\section{Trust Factor}

A survey conducted by NFO (2003), the public found out that "trust has a direct positive effect on brand preference and loyalty" (Harris, 2006). Other than that more than 40 percent respondent stated that they would definitely or probably start doing a business with a company or increase their business specifically because they consider the company is trustworthy."

Harlan Teller also described:

Consumer, investor, and employees all want to feel god about the company behind the brand. His view is supported by a 1997 Lou Harris poll that demonstrates that when you link a brand to a well-known and trusted corporate brand in the mind of a consumer, there is an increase in intent to purchase" (Harris, 2006).

The writer believes that trust will have a positive impact on the process of building the image of ICT education institute, and in the end also to support the sales of ICT education.

\section{Elaboration Likelihood Model}

In this study the writer will be using elaboration likelihood model in explaining how the people process the message of the ICT education institute, and also its correlation with the change of attitude towards the ICT education institute.

According to Petty \& Cacioppo, "the elaboration likelihood model attempts to explain different ways of processing messages, why different processing modes will be used, and the results of those processing modes on attitude change" (Miller, 2005). The elaboration likelihood model hypothesizes that there are two major routes to persuasion: the central and peripheral route. "The central route involves message elaboration, in which a great many cognitions (thoughts) about the message's arguments are generated by the individual receiving the message during the evaluation process." In contrast, "On the peripheral route, the receiver does not elaborate on the message through extensive cognitive processing of arguments. Instead, the receiver will rely on cues in the persuasion environment to guide the decision about message acceptance." 


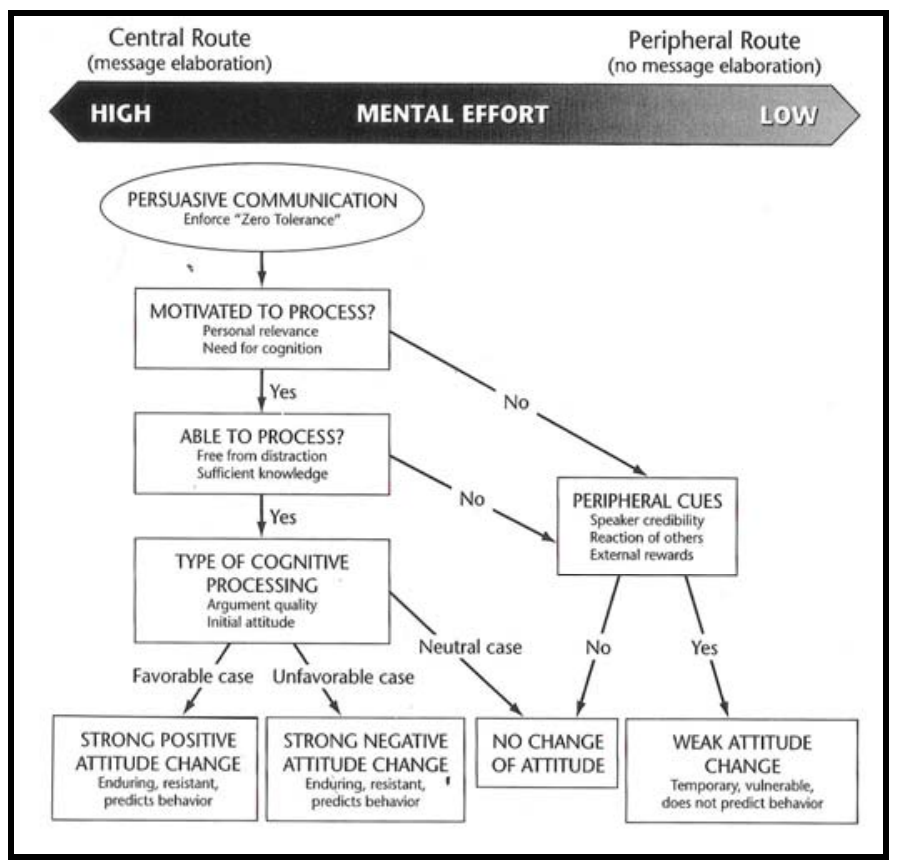

Figure 6 Elaboration Likelihood Model Source Griffin, 2003

\section{Conceptual Framework}

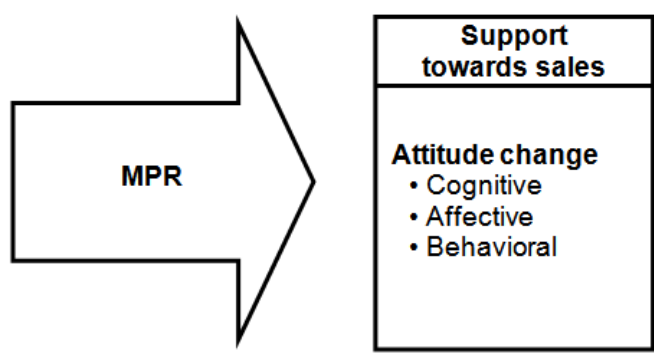

Figure 7 Conceptual Framework

As it was shown in the diagram above these conceptual frameworks tried to describe how the study will be done, the writer keen to find out how effective MPR is in generating the sales of ICT education, by observing the change of attitude towards the organization as a result of Marketing Public Relation activity.

\section{Research Design and Method}

By referring to the previous chapters, it is prudent for the writer to say that this study keen to find out the role of marketing communication strategies, that will lead to building the image of ICT education institute and how does the image influence enrollment decision. Therefore the writer approaches this study with an exploratory research design, with qualitative research method, and descriptive research designs that apply quantitative research method. Other than that the writer also uses direct observation to answer the research question. 
The writer seeks to find out, how Marketing Public Relations plays an important role in shaping the school image? By which that is believed to be the key factor in influencing consumer to enroll (support the sales). For that reason the goal of this research is to gather sufficient information regarding the most appropriate strategy to apply MPR in order to deliver persuasive message in building the image of ICT education institute, and also how the message is processed to create support towards the sales of ICT education.

Therefore it may lead the writer to the research question, which is: "How effective is Marketing Public Relations in supporting the sales of ICT education?”

In order to address those research question the writer will do the study from an interpretive perspective. Therefore the writer will apply the exploratory research design. The method used in this research is quantitative research method that "emphasis on using formulized standard question and predetermines response option in questionnaires or surveys administered to large numbers of respondent" (Hair et al, 2006).

\section{Data Gathering Procedure}

The fundamental data that will be used in this research are primary data and also the secondary data. Primary data "are collected especially to address a specific research objective" (Aaker et al, 2004). In this research the primary data will be collected through the research design and methods that the writer mention earlier in the previous paragraph. While secondary data is "data that are already available, because they were collected for some purpose other than solving the present problem." For this research the secondary data are collected from internal sources such as: internal records, customer database, and also external sources, in which are: published data source and computer retrieval database (i.e. internet).

\section{Quantitative Research Methods}

Other than qualitative research method, the writer will also emphasize the use of quantitative research methods. The writer uses this method to provide countable and non arguable data, in order to prove the notion that MPR is effective in influencing enrolment decision. According to Hair et al (2006), a quantitative research methods is "a research design that places heavy emphasize using formulized standard question and predetermine response option in questionnaires or surveys administered to large numbers of respondent."

The general procedures of data collecting in this research methods are mainly taken from surveys technique, which uses question and answer format. To gather the primary data the writer will apply self administered survey, self administered survey is "a data collection technique in which the respondent reads the survey questions and records his or her own answer with out the presence of a trained interviewer." In this survey techniques the questionnaire are given to the target sample directly to record their answer. This is done to seek out the reason behind the enrolment and to correlate them with Marketing Public Relations activities.

\section{Constructs and Measurement}

"Constructs is a hypothetical variable made up of set of component response or behavior that are thought to be related" (Hair et al, 2006). After knowing the construct it is important to develop it, hence it needs construct development, which is "an integrative process in which researchers determines what specific data should be collected for solving the defined problem." 
In this study focuses on one constructs that will be measured by the writer, these construct is the key concepts of the whole research. In which are as follows:

\section{Attitude}

One person attitudes consist of three components, "it is essential for Marketer and decision maker to understand all three components" (Hair et al 2006:391), and these components are (1) cognitive components (awareness), represents a subject's perception and knowledge a bout a specified object. In this case the writer measures the awareness and confidence of target group towards ICT education institute; (2) affective components (believe), represents a subject's emotional feelings toward the given object. The writer measures, target groups changed attitude towards ICT education institute, which influenced by a certain emotional attachment; (3) behavioral components (Enrollment Behavior).

It represents a subject's intended or actual behavior response to the given object. It is an observable outcome driven by interaction of a person's cognitive and affective component as they relate to a particular object. The writer will measure the act of enrollment in correlation with the persuasive message. For this constructs the writer will employ the use of quantitative research method, in order to find out the effectiveness of MPR strategy to support the sale of ICT education.

\section{Sampling and Respondents}

The data will be collected through self administered survey at BINUS Center outlet (ICT training center), the samples are taken from the training participant that have already joined BINUS Center's ICT training course. From the survey the writer tries to identify the reason behind their enrolment decision, based on the attitude construct (awareness, believe, \& buying behavior). The surveys will be submitted directly to the target sample, and since it is self administered survey the presence of the researcher are not needed.

\section{Data Analysis Procedure}

This research will use chi square analysis, to study relationship among variables. From this data the writer hopes to determine the relationship between MPR and the decision to enroll. In analyzing this data the writer will employ SPSS software, using the cross tabulation analysis to determine the existence of such relationship.

Chi-square $\left(\mathrm{X}^{2}\right)$ analysis permits the writer to test "for significance between the frequency distribution for two (more) nominally scaled variables in cross tabulation table to determine if there is any association" (Hair et al, 2006). The purpose of cross tabulation is to determine whether certain variables differ when compared among various sub groups. By using cross tabulation analysis from the SPSS software the writer my try to calculate the $\mathrm{X}^{2}$ value using a simple equation of:

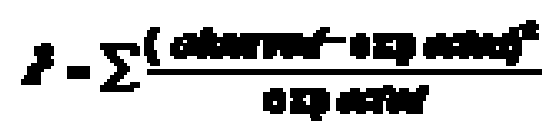

Where:

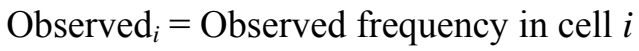

Expected $_{i}=$ Expected frequency in cell $i$

$\mathrm{n}=$ Number of cells 
By this equation the writer hopes to determine that whether there are relationships between Marketing Public Relations strategies with the enrolment rate (sales rate) towards ICT education based on its awareness, believe and buying behavior.

\section{Quantitative Research Analysis}

Due to the close research site the return rate of the questionnaire is almost up to $61 \%$. The result is specified as in (1) 100 questionnaires are completed properly; (2) 45 questionnaire are returned with a lot of empty answers; (3) 20 questionnaire did not return.

\section{Respondent Profile}

From the data collected it shows the age of respondent are dispersed in to the Table 1 below.

Table 1 Age of Respondent

\begin{tabular}{lrrrrr}
\hline & Frequency & Percent & $\begin{array}{c}\text { Valid } \\
\text { Percent }\end{array}$ & $\begin{array}{c}\text { Cumulative } \\
\text { Percent }\end{array}$ \\
\hline Valid & $12-14$ & 12 & 12.0 & 12.0 & 12.0 \\
& $15-17$ & 18 & 18.0 & 18.0 & 30.0 \\
$18-22$ & 36 & 36.0 & 36.0 & 66.0 \\
$23-28$ & 17 & 17.0 & 17.0 & 83.0 \\
& $29-35$ & 9 & 9.0 & 9.0 & 92.0 \\
$>35$ & 8 & 8.0 & 8.0 & 100.0 \\
& Total & 100 & 100.0 & 100.0 & \\
\hline
\end{tabular}

In addition to that date the writer also collected the data of the education status of the respondent, in which detailed in the Table 2 below.

Table 2 Education level of Respondent

\begin{tabular}{llrrrr}
\hline & & Frequency & Percent & $\begin{array}{c}\text { Valid } \\
\text { Percent }\end{array}$ & $\begin{array}{c}\text { Cumulative } \\
\text { Percent }\end{array}$ \\
\hline Valid & SMP & 12 & 12.0 & 12.0 & 12.0 \\
& SMU & 18 & 18.0 & 18.0 & 30.0 \\
& SARJANA & 70 & 70.0 & 70.0 & 100.0 \\
& Total & 100 & 100.0 & 100.0 & \\
\hline
\end{tabular}

From the description above the writer will approach this research based upon three variables stated in the above paragraph, from this variable the writer tries to find out the effectiveness of MPR strategy in term of awareness (cognitive), believe (affective) and also buying behavior (behavioral).

\section{Awareness (Cognitive)}

Awareness could be gained differently among each customer, based on the profile above the writer sought out what invoke awareness in the consumer mind based on the age of the respondent, this are selected by the user to find out the effectiveness of brochure, referrals and Publication according to the age of the respondent. 


\section{Awareness through Brochure}

Based on the findings the writer will evaluate the effectiveness of advertising to invoke awareness towards the mind of the consumer, based on the customer age, in which are as in Table 3 .

Table 3 Chi-Square on awareness through brochure

\begin{tabular}{lccr} 
& Value & Df & Asymp. Sig. (2-sided) \\
\hline Pearson Chi-Square & $46.809(a)$ & 5 & .000 \\
Likelihood Ratio & 28.758 & 5 & .000 \\
Linear-by-Linear & 15.819 & 1 & .000 \\
$\begin{array}{l}\text { Association } \\
\text { N of Valid Cases }\end{array}$ & 100 & & \\
\hline \multicolumn{4}{c}{ a 6 cells (50.0\%) have expected count less than 5. } \\
\\
The minimum expected count is .48.
\end{tabular}

From the table above the writer may conclude that if $\alpha=0.005 \geq$ Asymp. Sig. (2-sided), it means $\mathrm{Ha}$ accepted and Ho rejected. If $\mathrm{Ha}$ accepted it means that there are a significant relationship between age and awareness through brochure. Therefore the writer may conclude that brochure is effective to invoke awareness from the target audience

\section{Awareness through Referral}

Besides on brochure the writer will also analyze other possibility that could invoke target market awareness, and one of them is referral. Based on the data findings the writer detailed as follows:

Table 4 Chi-Square tests on awareness through referral

\begin{tabular}{lccr}
\hline & Value & df & Asymp. Sig. (2-sided) \\
\hline Pearson Chi-Square & $31.271(\mathrm{a})$ & 5 & .000 \\
Likelihood Ratio & 15.491 & 5 & .008 \\
$\begin{array}{l}\text { Linear-by-Linear } \\
\text { Association }\end{array}$ & 5.451 & 1 & .020 \\
N of Valid Cases & 100 & \\
\hline \multicolumn{4}{c}{ a 6 cells (50.0\%) have expected count less than 5. } \\
The minimum expected count is .24.
\end{tabular}

From the table above the writer may conclude that if $\alpha=0.005 \geq$ Asymp. Sig. (2-sided), it means $\mathrm{Ha}$ accepted and Ho rejected. If $\mathrm{Ha}$ accepted it means that there are a significant relation ship between age and awareness through referral, which means that referral strategy is effective in supporting the sale of ICT education institute. However referral is a lot more effective if it was done by a credible source. From the writer's analysis the cross-tab table result the effective target for referral is people in the age range of 18-22, which can be seen in the Figure 6 below. 


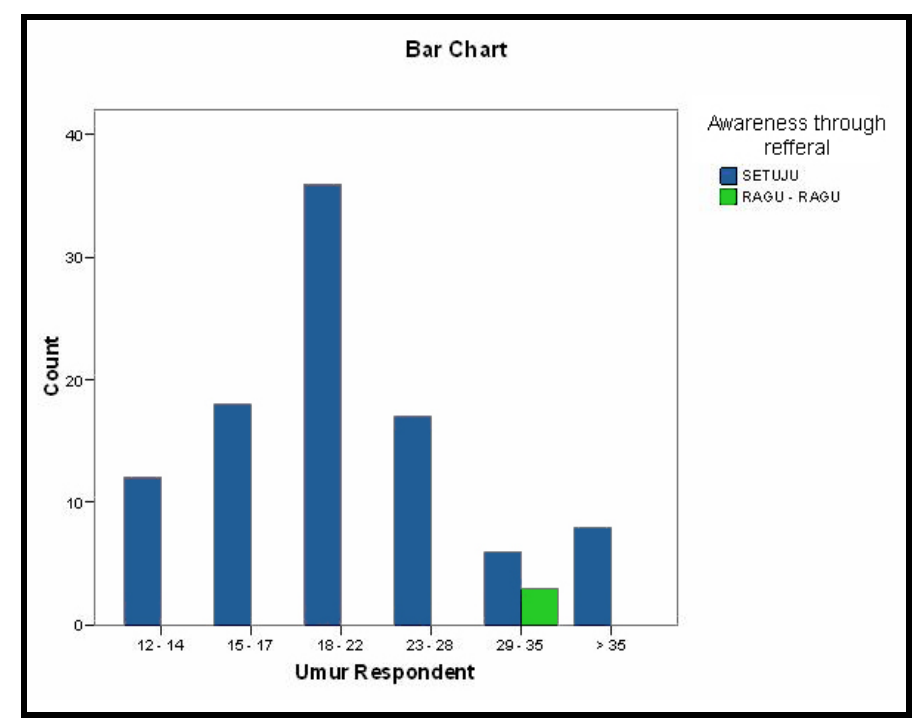

Figure 8 Chart on Awareness through Referrals

Deriving from the chart above the writer conclude that referral are an effective tools for gaining awareness especially towards the target market in the age of 18-22 years old. However in the age of 29-35 years old referral may face several negative responses from the people that are skeptical about the message.

\section{Awareness through Publication}

The research findings for this section are highly intertwined with the previous one, since the age of 18-22 are more sensitive towards referrals, the writer believes that ages also plays a part on publication, which explained in the Table 5 below.

Table 5 Chi-Square tests on awareness through publication

\begin{tabular}{lccr} 
& Value & df & $\begin{array}{c}\text { Asymp. Sig. } \\
\text { (2-sided) }\end{array}$ \\
\hline Pearson Chi-Square & $63.145(\mathrm{a})$ & 10 & .000 \\
Likelihood Ratio & 49.610 & 10 & .000 \\
Linear-by-Linear & 4.730 & 1 & .030 \\
Association & 100 & & \\
N of Valid Cases & \multicolumn{4}{c}{ a 11 cells (61.1\%) have expected count less than 5. } \\
\multicolumn{4}{c}{ The minimum expected count is .48. }
\end{tabular}

From the table above the writer may conclude that if $\alpha=0.005 \geq$ Asymp. Sig. (2-sided), it means $\mathrm{Ha}$ accepted and $\mathrm{Ho}$ rejected. If $\mathrm{Ha}$ accepted it means that there are a significant relationship between age and awareness through publication. Especially in the age bracket 18-22 years old.

\section{Believe}

The derivation of awareness would be believe. In this state the writer emphasize on the emotional side of the target market regarding BINUS Center and how to obtain it. Because awareness alone does not always lead to sale, it has to evolve. This state will define the effectiveness of Brochure, referrals and Publication according to the education level of the respondent. 


\section{Believe through Brochure}

Based on the findings the writer will evaluate the effectiveness of advertising in the process to form trust and believe towards BINUS Center, the analysis will be detailed further more on Table 6 below.

Table 6 Chi-Square on Believe through Brochure

\begin{tabular}{lrrr} 
& Value & df & $\begin{array}{c}\text { Asymp. Sig. } \\
\text { (2-sided) }\end{array}$ \\
\hline Pearson Chi-Square & $17.505(\mathrm{a})$ & 4 & .002 \\
Likelihood Ratio & 25.457 & 4 & .000 \\
Linear-by-Linear & 13.096 & 1 & .000 \\
Association & 100 & & \\
N of Valid Cases & \multicolumn{1}{c}{ a 4 cells (44.4\%) have expected count less than 5. } \\
\multicolumn{2}{c}{ The minimum expected count is 1.32.}
\end{tabular}

From the table above the writer may conclude that if $\alpha=0.005 \geq$ Asymp. Sig. (2-sided), it means $\mathrm{Ha}$ accepted and Ho rejected. If $\mathrm{Ha}$ accepted it means that there is a significant relationship between education level and believe through brochure. Based on that data it shows that brochure also plays a significant role in generating believe.

\section{Believe through Referral}

The writer believes that referrals are invoked by trust; therefore people tend to believe information delivered by a credible source rather than the otherwise. In order to prove such notion the writer will cite the research findings that shows the effectiveness of referral in creating believe.

Table 7 Chi-Square tests on believe through referral

\begin{tabular}{lrrr} 
& Value & df & $\begin{array}{c}\text { Asymp. Sig. } \\
(2 \text {-sided })\end{array}$ \\
\hline $\begin{array}{l}\text { Pearson Chi- } \\
\text { Square }\end{array}$ & $5.638(\mathrm{a})$ & 4 & .228 \\
$\begin{array}{l}\text { Likelihood Ratio } \\
\text { Linear-by-Linear }\end{array}$ & 8.781 & 4 & .067 \\
Association & 1.031 & 1 & .310 \\
N of Valid Cases & 100 & & \\
\hline a 5 cells (55.6\%) have expected count less than 5. \\
\multicolumn{4}{l}{ The minimum expected count is .72. }
\end{tabular}

From the table above the writer may conclude that if $\alpha=0.005 \geq$ Asymp. Sig. (2-sided), it means Ho accepted and Ha rejected. If Ho accepted it means that there is no significant relationship between education levels and believe through referral. As the writer stated in the above paragraph believe is formed through referral activity. Since there are no strong relationship with education level, referral may works on all different level of education. In order to prove this argument the writer cited the chart resulted from the analysis. 


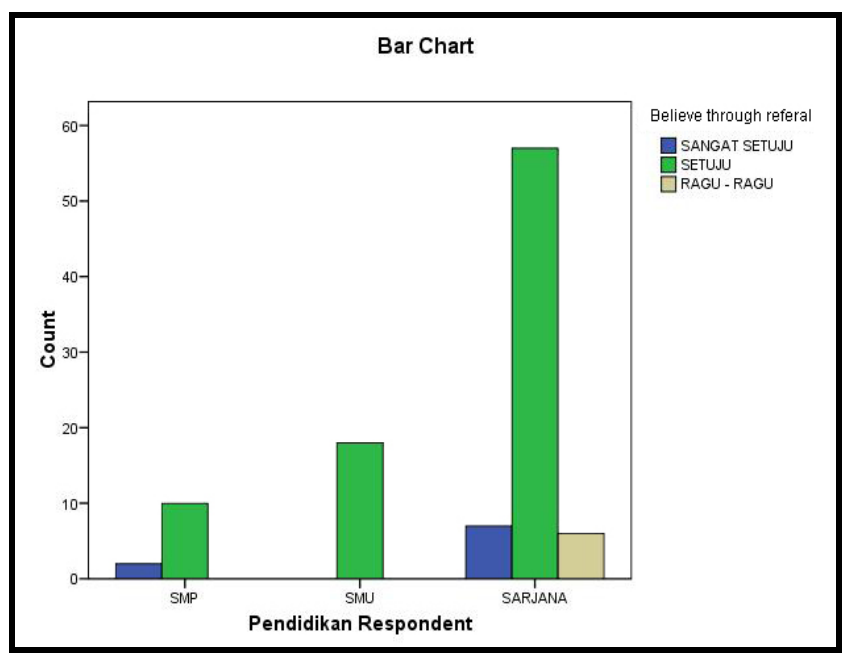

Figure 9 Chart on Believe through referral

\section{Deriving}

From the chart above it is prudent to conclude that, believe are conjured by act of referral. However statically there is no relationship between level of education with believe through referral because as the writer stated in the above paragraph referral works for all level of education.

\section{Believe through Publication}

Publication is another variable taken by the writer to prove that publication will also build believe. For publication MPR rely heavily on the media support:

Table 8, Chi-Square tests on believe through publication

\begin{tabular}{lrrr}
\hline & Value & df & $\begin{array}{c}\text { Asymp. } \\
\text { Sig. (2- } \\
\text { sided) }\end{array}$ \\
\hline Pearson Chi-Square & $7.563(\mathrm{a})$ & 4 & .109 \\
Likelihood Ratio & 11.801 & 4 & .019 \\
Linear-by-Linear & 6.023 & 1 & .014 \\
Association & 100 & & \\
N of Valid Cases & & & \\
\hline
\end{tabular}

a 5 cells $(55.6 \%)$ have expected count less than 5 .

The minimum expected count is .36 .

From the table above the writer finds out that $\mathrm{X}^{2}$ from calculation are $>$ then $\mathrm{X}^{2}$ from the table therefore $\mathrm{Ha}$ accepted and Ho rejected. If $\mathrm{Ha}$ accepted means that there is a significant relationship between education level and believe through publication. The table above clearly shows the effectiveness of publication towards, people that has higher education. Therefore, if BINUS Center is willing to consider publication as their MPR strategy then they should relate with that results

\section{Behavior}

The writer agrees that believe could invoke action or in this case buying behavior, in this state the writer seeks to find out the effectiveness of advertising, referrals and Publication towards consumer behavior, this are viewed from the age level of the respondent. 


\section{Behavior through Brochure}

Based on the findings the writer will evaluate the effectiveness of brochure in the process to invoke behavior or $\mathrm{n}$ this case buying behavior towards BINUS Center's ICT training course, the analysis will be detailed further more in Table 9 below.

Table 9 Chi-Square on behavior through advertising

\begin{tabular}{lrrr} 
& \multicolumn{1}{c}{ Value } & Df & $\begin{array}{c}\text { Asymp. Sig. } \\
\text { (2-sided) }\end{array}$ \\
\hline Pearson Chi-Square & $138.196(\mathrm{a})$ & 10 & .000 \\
Likelihood Ratio & 146.820 & 10 & .000 \\
Linear-by-Linear & 36.620 & 1 & .000 \\
Association & 100 & & \\
N of Valid Cases & & & \\
& & & \\
\hline
\end{tabular}

a 10 cells $(55.6 \%)$ have expected count less than 5.

The minimum expected count is .64 .

From the table above the writer may conclude that if $\alpha=0.005 \geq$ Asymp. Sig. (2-sided), it means Ha accepted and Ho rejected. If Ha accepted it means that there is a significant relationship between age and buying behavior in result of brochure. However this significant relationship does not meant that brochure is highly effective in creating buying behavior, based on the chart below, the percentage for people buying from brochure very minimal.

Figure 10 Chart on behavior through brochure

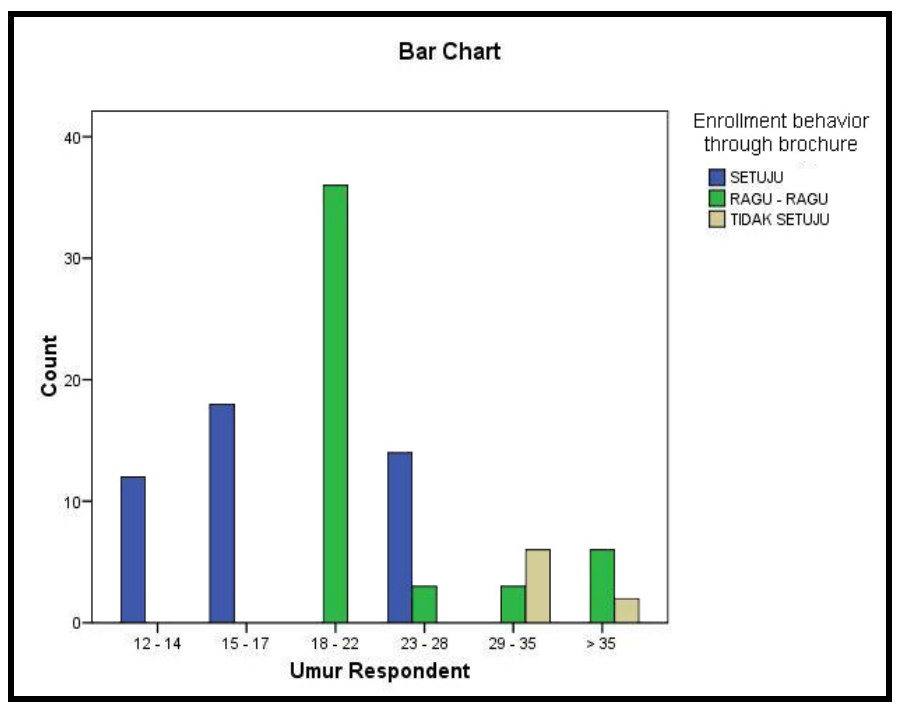

\section{Behavior through Referrals}

The writer seeks to find out whether referrals could generate enrollment behavior (buying behavior), quantitative research result it shows that referral play a significant role in influencing the target market, in which are explained as in Table 10 below. 
Table 10 Chi-Square tests on behavior through referral

\begin{tabular}{lccc}
\hline & Value & df & $\begin{array}{c}\text { Asymp. Sig. } \\
\text { (2-sided) }\end{array}$ \\
\hline Pearson Chi-Square & $100.000(\mathrm{a})$ & 10 & .000 \\
Likelihood Ratio & 55.754 & 10 & .000 \\
Linear-by-Linear Association & 32.300 & 1 & .000 \\
N of Valid Cases & 100 & & \\
\hline
\end{tabular}

a 12 cells $(66.7 \%)$ have expected count less than 5 .

The minimum expected count is .24.

From the table above the writer may conclude that if $\alpha=0.005 \geq$ Asymp. Sig. (2-sided), it means that $\mathrm{Ha}$ is accepted and Ho rejected. If $\mathrm{Ha}$ accepted it means that there is a significant relationship between age and behavior through Referral, therefore the writer is led to believe that referrals plays the most significant role in generating buying behavior.

\section{Behavior through Publication}

Here the writer seeks to find out whether Publication has an effect on behavior. In correlation with that the writer tries find the correlation of enrollment behavior with publication effort by BINUS Center:

Table 11 Chi-Square tests on behavior through Publication

\begin{tabular}{lrrr}
\hline & \multicolumn{1}{c}{ Value } & df & $\begin{array}{c}\text { Asymp. Sig. } \\
(2 \text {-sided })\end{array}$ \\
\hline Pearson Chi-Square & $38.662(\mathrm{a})$ & 10 & .000 \\
Likelihood Ratio & 37.881 & 10 & .000 \\
Linear-by-Linear & .219 & 1 & .640 \\
Association & & & \\
N of Valid Cases & 100 & &
\end{tabular}

a 12 cells (66.7\%) have expected count less than 5 .

The minimum expected count is .24 .

From the table above the writer finds out that $\alpha=0.005 \geq$ Asymp. Sig. (2-sided), it means that $\mathrm{Ha}$ is accepted and Ho rejected. If Ha accepted it means that there is a significant relationship between age and enrollment behavior through publication.

Figure 11 Chart on buying through Publication

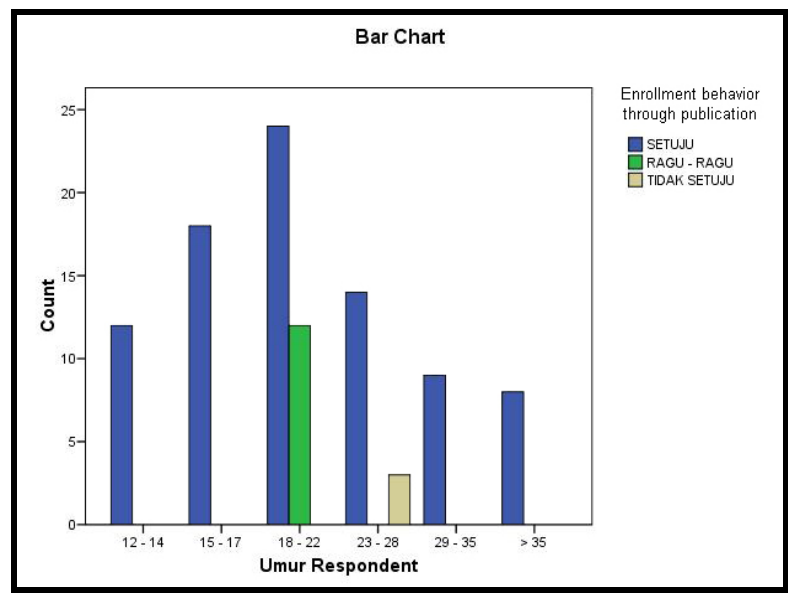


The chart above clearly shows the effectiveness of publication towards people in the age of 18-22 years old. However there are several people in that area are also skeptical to publication. Therefore if BINUS Center should channel their MPR strategy towards that segment only (18-22 years old age bracket).

\section{CONCLUSSION}

Based on the research analysis done in the chapter 4, therefore the writer will conclude the result of this research into several points, in which are tt is proven that Marketing Public Relation has significant role in promoting ICT education, especially in creating awareness, trust and enrollment behavior towards BINUS Center. For BINUS Center, awareness can be gain through referral activity. Other than that brochure also has prominent effect towards awareness. Advocacy or referral have dominant effect in building trust (believe), other than that Publication also play a role in creating a trustworthy image towards BINUS Center. Referral plays an important part in shaping enrollment behavior towards BINUS Center. Other than that publication are also useful to create trustworthy image and reason to buy for the customer. Marketing Public Relation is an effective marketing strategy for ICT education. Especially towards BINUS Center's target market. Based on the quantitative research the majority of BINUS Center target market is in the age bracket 18-22 years old. In correlation with that fact the qualitative research has shown that MPR is effective in supporting the enrollment decision towards BINUS Center.

\section{REFERENCES}

Aaker, D. A., Kumar, V. D., \& Goerge, S. (2004). Marketing research. USA: John Wiley \& Sons.

Alifahmi, H. (2008). Marketing Communication Orchestra, Harmonisasi Iklan, Promosi, dan Marketing Public Relation. Bandung: Examedia Publishing.

Copley, P. Marketing Communications Management, concept \& theories, cases \& practices. (2004). Oxford: Elsevier Butterworth-Heinemann.

Hair, J. F., Bush, R. P., \& Ortinau, D. J. (2006). Marketing Research. New York: McGraw-Hill.

Kim, Y. C. (2003). Adapting Education to the Information Age. White paper.

Kotler, P., Hermawan, K., \& Junardy, J. W. (2003). Indonesia 3.0: The ICT Perspective, Creating New Culture for Building Next Civilization. White Paper.

Kotler, P., \& Armstrong, G. (2004). Principles of Marketing. New Jersey: Pearson Prentice Hall.

Kozma, R. B. (2005). ICT, Education Reform, and Economic Growth. White Paper.

Miller, K. (2005). Communication Theories: Perspective, Process, and Contexts. New York: McGraw-Hill.

Nandika, D. Pendidikan ditengah gelombang perubahan, Jakarta: LP3ES Indonesia.

Ranchold, A., Gurau, C., \& Lace, J. On-line messages: developing an integrated communications model for Bio technology companies. An International Journal Volume 5. Number 1. 2002. pp. 6-18. 